\title{
WORLD REVIEW OF THE NATURAL ENEMIES AND DISEASES OF SPODOPTERA LITURA (F.) (LEPIDOPTERA: NOCTUIDAE) ${ }^{\circ}$
}

\author{
G. V. RANGA RAO, J. A. WIGHTMAN and D. V. RANGA RAO \\ Legumes Entomology, International Crops Rescarch Instutute for the Semi-Arid Tropics, \\ (ICRISAT), Patancheru P.O. 502 324, Andhra Pradesh, India
}

(Reccived 5 February 1991; accepted 1 Fchruary 1992)

\begin{abstract}
Published information was used to compile a summary of natural enemies (parasitoids, predators and diseases) reported attacking Spodoptera litura $(\mathbf{F})$ under field conditions. Species (71) of insect parasitoids in seven families of Hymenoptera and two families of Diptera were listed as parasitoids of different stages of $S$. litura. Predatory insects (36) belonging to 14 families and 12 species of spiders from six families have been reported to feed on this species. Four protozoan, four fungal, seven bacterial, four each of viral and nematode species were also reported to be the pathogens of this species. Published information suggested that periodic releases of large number of egg parasites could help in suppressing populations of this pest. There is a considerable scope for increased attention to the role of natural enemies as component of integrated pest management programmes of $S$. litura.
\end{abstract}

Key Words: Spodoptera litura, natural enemics, discases

Résumé - Compte rendu mondial des ennemis naturels et des maladies de Spodoptera litura (F.) (Lépidoptéres: Noctuides): Des informations publićes ont servi de source pour la compilation de ce compte rendu des ennemis naturels (parasites et prédateurs) et des maladies qui s'attaquent à Spodoptera litura (F.) en milieu réel. Soixante-neuf espèces d'insectes parasitoïd parmi sept familles des Hyménoptéres ainsi que de familles des Diptères sont classées comme parasites des différents stades de $S$. litura. Trente-six insectes prédateurs, appartenant à 14 familles ct 12 espèces d'araingnées provenant de six familles se nourriraient de cette espèce. Quatre protozoares, quatre moisissures, sept bactéries, quatre virus et cinq nematodes seraient également des agents pathogènes de cette espèce. Les information publiées laissant à croire que des introductions périodiques des parasites des oeufs en grands nombres permettraient de supprimer la population de Spodoptera. Les ennemis naturels offrent des possiblités importantes pour jouer un rôle clé dans des programmes de lutte intégrée contre $S$. litura.

Mots Clés: Spodoptera litura, ennemis naturels, maladies

\section{INTRODUCTION}

The tobacco caterpillar, Spodoptera litura $(\mathrm{F}$.) is one of the most important insect pests of agricultural crops in the Asian tropics. This species is widely distributed throughout tropical and temperate Asia, Australasia and the Pacific Islands (Feakin, 1973; Kranz et al., 1977). It is a polyphagous pest and

"Submitted as Journal Article No. 1076 by the International Crops Research Institute for the Semi-Arid Tropics, Patancheru 502 324, Andhra Pradesh, India. known to cause severe damage to many crops including tobacco and groundnut in India (Moussa et al., 1960; Ayyanna et al., 1982).

The "green revolution" in Asia brought with it an increased awareness of the potential of insecticides for increasing the sustainability of rice production. Unfortunately, the involvement of farmers in insecticide related technologies did not proceed as fast as the rate of subsidy spread and the overspill of insecticide usage into the fields of legume growers and horticulturalists. Legume pests are increasing in 
economic importance all through Asia due to the destruction of natural control systems, and the buildup of insecticide resistance following the "spraymania" of many farmers. If this is to be counteracted, natural control needs to be given increased emphasis as a component of IPM approach. $S$. litura populations in groundnut fields (our study crop) are increasing in number and intensity, especially in fields where insecticides have been applied (Ranga Rao and Shanower, 1988; Stechmann and Semisi, 1984).

In the past, the control of arthropods depended mostly on inexpensive and efficient insecticides. But in recent years populations of many pests including $S$. litura have developed resistance to many commercially available pesticides (Ramakrishnan et al., 1984). Moreover, outbreaks of secondary pests, and the effect of pesticides on non-target organisms is becoming increasingly common. Because of these reasons, the control of arthropod pests is becoming increasingly difficult and it is vital that all biological alternatives to insecticides need to be given greater priority, both in research and application.

Although $S$. litura is known to cause substantial damage to a number of crops, there has been no attempt to review the literature on the role of natural enemies in regulating the abundance of this pest. The main purpose of this paper is to review the status of natural enemies of $S$. litura on global basis. S. litura is known to be attacked by many of natural enemies at various life stages. Altogether, about 131 species of natural enemies have been reported from different parts of the world (Table 1). The list of parasites, predators and diseases was compiled from published literature, and arranged in a systematic order that includes host stage attacked, scientific name, family and geographic distribution, followed by the most pertinent references (Table 2). The information furnished in this paper may suggest new sources of natural enemies for different geographic regions. It may also indicate the potential importance of different natural enemies which may be relevant to future biocontrol and IPM projects.

\section{EGG PARASITOIDS}

Four species of trichogrammatids, one scelionid and one braconid which had been reported as egg parasitoids of S. litura, Chelonus sp. and Telenomus spp., have also been reported as both egg and larval parasitoids. A total of $10 \mathrm{egg}$ parasitoids have been reported from different parts of the host distribution (Table 2). Among the trichogrammatids, $T$. australicum and $T$. chilonis from India (Joshi et al., 1979; Patel et al., 1971), T. japonicum from Indonesia (Chu, 1979), $T$. dendrolimi from China (Chiu and Chou, 1976), are the most common. These species are often reported from eggs of several other hosts.

Mass releases of an indigenous egg-larval parasite Chelonus helipae in 1971-1973 in Anand, Gujarat, India, against $S$. litura in cauliflower crop proved ineffective in controlling the pest. During 1974, weekly release of Telenomus remus Nixon, an exotic egg-larval parasitoid, in a tobacco nursery did not result in any parasitism. However, five weekly releases of 50,000 parasites $/ 0.2$ ha and two teleases of 15,000 parasitoids $/ 0.2$ ha in cauliflower, resulted in 60\% parasitism (Patel et al., 1979).

Rao et al. (1979) observed $8 \%$ parasitization by Chelonus blackburni Cameron an egg/larval parasitoid of S. litura in Karnataka, India. An insect survey conducted in Jawa Timur, Indonesia revealed the occurrence of the parasitoids Trichogramma japonicum Ashm. and Telenomus dignus (Gah) attacking S. litura eggs (Chu, 1979). Chiu and Chou

Table 1. Spodoptera litura natural enemies and diseases worldwide

\begin{tabular}{lcccc} 
& \multicolumn{4}{c}{$\begin{array}{c}\text { Number of natural cnemy species and diseases } \\
\text { reported from different countries }\end{array}$} \\
\cline { 2 - 5 } & Parasitoids & Predators & Nematodes & Diseases \\
\hline India & 44 & 24 & 4 & 13 \\
Australia & 5 & 1 & - & - \\
Japan & - & 8 & 1 & 4 \\
China & 12 & 7 & - & 3 \\
Indonesia & 4 & 1 & - & - \\
Western Samoa & 8 & 4 & - & - \\
Papua New Guinea & - & 4 & - & - \\
Philippines & 1 & - & - & - \\
New Zealand & 1 & - & - & 2 \\
\hline Total & 71 & 48 & 4 & 20 \\
\hline
\end{tabular}

${ }^{*}$ Spiders are included. 
Table 2. Natural enemies and diseases of Spodoptera litura (Fabricius)

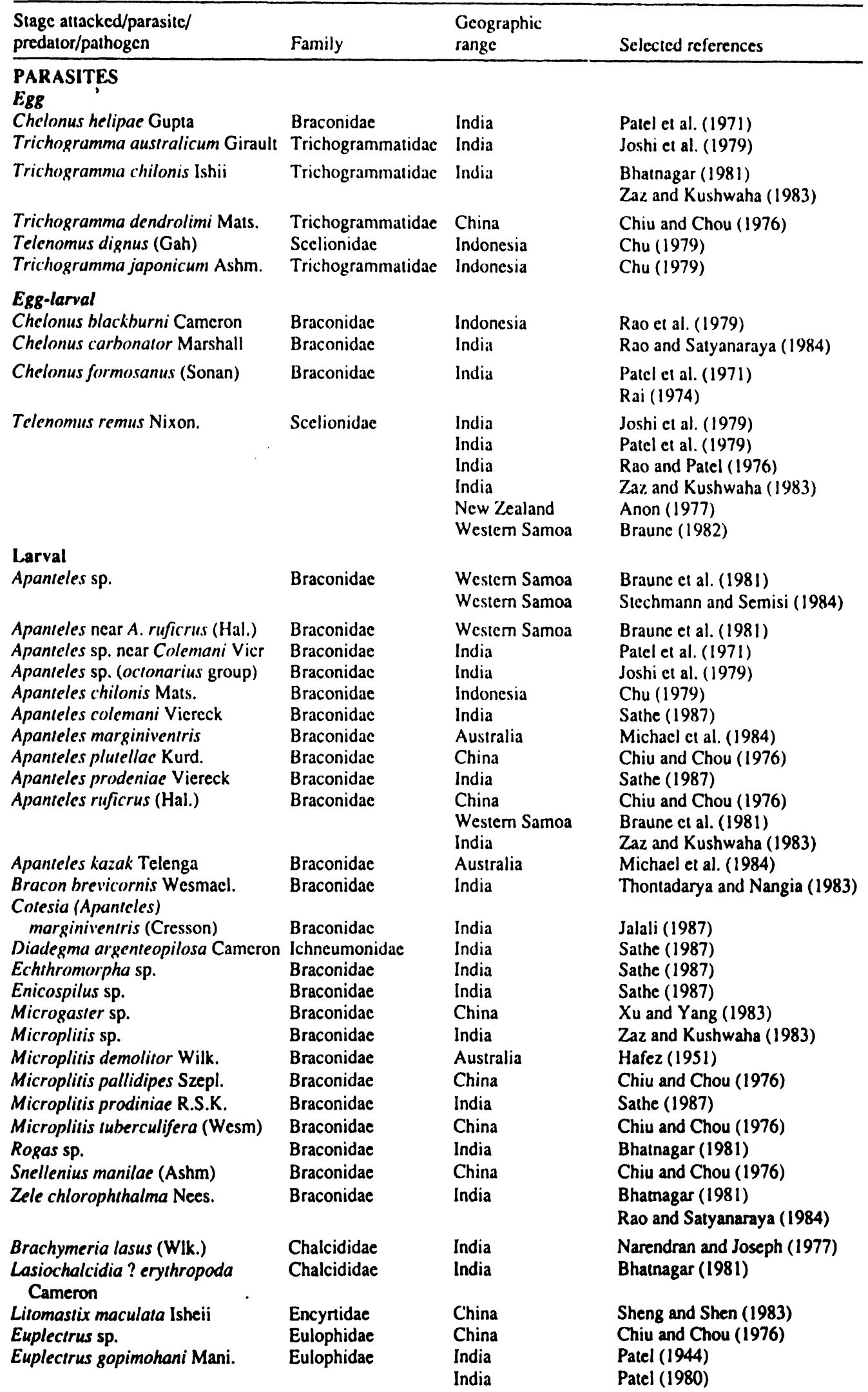


Table 2 Contd.

Stage attacked/parasite/ predator/pathogen

Euplectrus near E. xanthocephalus Tetrastichus ayyari Rohwer

Trichospilus pupivora Ferri

Campoletes sp.

Campoletes chloridcae Uchida

Charops bicolor (Szepi)

Charops obstusus Morl.

Hyposoter didymator Thunb.

Erioborus sp.

Ichneumon sp.

Netelia ferruginea Cameron

Paniscus productus Brulle

Temelucha biguttula (Mats.)

Fannia leucostica Smith

Actia nigritula Mall.

Parasarcophaga misera (Walk.)

Peribaea orbata (Wideman)

Strobliomyia aegyptia Vill.

Sturmia acqualis Mall.

Tritaxys sp.

Winthemia near dispar (Macq.)

Pre-pupal

Chelonus sp.

Pupal

Brachymeria sp.

Hybothoracini sp.

Sarcophaga albiceps Meigen

Sarcophaga dux Thoms

Sarcophaga peregrina

(Robineauedesvoidy)

Blepherella setigera Corti

Winthemia sp.

PREDATORS

Egg

Chalcid wasp (unidentified)

Cardiocondyla nuda (Mayr)

Tapinoma melanocephalum (F.)

Liposcelis sp.

Egg-lar val

Chrysopa crassinervis

Esben Peterson

Small red ants (unidentified)

Nesidiocoris tenuis Reuter

Conocephalus sp.

\section{Larval}

Carabid beetles (unidentified)

Crickets (unidentified)

Earwigs (unidentified)

Casnoidea indica (Thnb.)

Chrysopa sp.

Coccinella sp.

Epilachna sp.

Dieuches sp.

Oechalia consocialis.(Bois.)
Family

Eulophidac

Eulophidae

Eulophidae

Ichncumonidae

Ichncumonidae

Ichneumonidae

Ichneumonidae

Ichneumonidae

Ichneumonidac

Ichneumonidac

Ichneumonidae

Ichneumonidae

Ichneumonidae

Muscidae

Tachinidac

Tachinidac

Tachinidae

Tachinidae

Tachinidac

Tachinidac

Tachinidae

Braconidae

Chalcididae

Chalcididac

Sarcophagidae

Sarcophagidac

Sarcophagidae

Tachinidac

Tachinidac

Chalcididac

Formicidae

Formicidae

Liposcelidae

Chrysopidae

Formicidae,

Miridae

Tettigonidae

Carabid

Carabidae

Chrysopidae

Coccinellidae

Coccinellidae

Lygaeidae

Pentatomidae
Geographic

range

Western Samoa

India

India

India

India

India

China

China

India

Australia

India

India

India

Australia

Indonesia

India

Australia

India

India

Philippines

India

India

India

American Samoa

Australia

American Samoa

Western Samoa

India

India

India

India

India

India

Western Samoa

Western Somoa

Western Somoa

Western Somoa

India

India

Western Somoa

India

China

Japan

Japan

Japan

Indonesia

India

India

India

India

Australia

Hafez (1951)
Braune and Kan (1981)

Joshi et al. (1979)

Braune and Kan (1981)

Selected references

'Braune et al. (1981)

Sathe (1987)

Sathe (1987)

Battu (1977)

Battu (1977)

Sathe (1987)

Chiu and Chou (1976)

Chiu and Chou (1976)

Patel (1980)

Michael et al. (1984)

Bhatnagar (1981)

Anon. (1988)

Sathe (1987)

Hafez (195I)

Chu (1979)

Zaz and Kushwaha (1983)

Bhattu (1977)

Jayanth and Nagarkatti (1984)

Rao and Patel (1976)

Bhatnagar (1981)

Joshi et al. (1979)

Patel et al. (197!)

Hoyt (1955)

Hafez (1951)

Hoyt (1955)

Thontadarya and Nangia (1983)

Rao et al. (1981)

Bhatnagar (1981)

Joshi et al. (1979)

$\mathrm{Zaz}$ and Kushwaha (1983)

Braune and Kan (1981)

Braune and Kan (1981)

Braune and Kan (1981)

Zaz and Kushwaha (1983)

Rao and Satyanaraya (1984)

Braune (1980)

Patel (1980)

Deng and Jim (1985)

Ito et al. (1972)

Ito et al. (1972)

Ito et al. (1972)

Chu (1979)

Sitaramaiah and Ramaprasad (1982)

Sitaramaiah and Ramaprasad (1982)

Cherian and Brahmachari (1942)

Rao et al. (1981)

Richard (1964) 
(LL6I) כXPPEYd pure OEY

(8L6I) oby pure oxpeyd

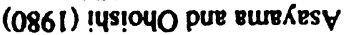

(E861) вцем4sny pue 28Z (L96I) je jo КyLnureurey (zL6I) 'je ia nueg

(8L61) ' je ja Ies (L861) UuaM pue! 7 (0861) Кㅇํ!M pue วuо태 (9L61) 2qeurje $M$

(6L6I) fereke[ pue ueuekeJeN

(S86I) EAEISEA!JS pUE JEIOURYG (ZL6I) ' [E 10 OII (SL6I) 48u!S pur y (SL6I) 48u!S pue 48u!S

(086I) 'ן 10 ye!eus. (0861) 'ן 10 पе!eusese!! (086I) ' ן 10 ye!eurespi!s (0861) ' je 10 yeiewesel!s (0861) ' ' 10 4E!ruesel!S

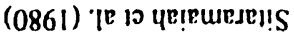
(0861) ' p 10 ye!nusesel!s

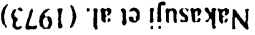
(086I) ' 10 ye!ruese!!s

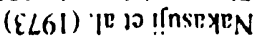

(0861) ' [e 10 ye!reuese!!S

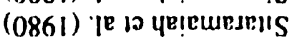

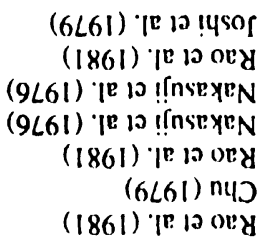

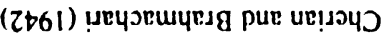

(\$861) eאeseuekies pur ory

(ZL6I) UESSRH

(¿L6I) URSSeH

(SL6I) ' je to ye!eurese!!S

(zL61) uesseH

(2861) pesesdrupy pue ye!̣ursel!S (†861) uगy

(2861) pesesdeury pue ye!rutesp!!S

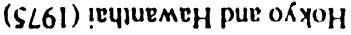

(ZL61) unsseH

(SL61) nus pue nuJ

(9L61) IEMEd

\section{e!puI}

ueder

в!pu

e!pul

ह!̣u

EUI!)

Eu!Yว

purjerZ MaN

urdes

e!pul

!pul

ueder

e!pu]

в!̣pu

e!pu

etpul

p!pul

в!pu

в!pu

в!puI

e!puI

urde?

etpuI

under

p!pu

nipuI

oxp!uo!qnio

sepiuorgnio

psez!| ysng

psez!| ysing

วep!sịоนчL

oxp!s!uroy $\perp$

әxp!s!!|pS

oep!o!lyes

oxp!?!!|!S

aepido $\times \mathrm{O}$

aepido $K \times \mathrm{O}$

sep!juryd אuग!W sup!podosoloH วหp!uo!qniว (2)

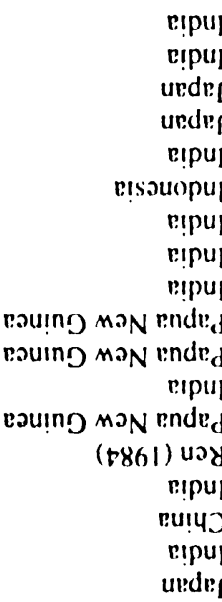

Eauing MaN ende

(SL61) 'p 10 Joodr:y nu!4) r!pul arp!dso $\Lambda$

әep!ds $\curvearrowright \Lambda$

orp!dso $\Lambda$

orpidso $\Lambda$

otpidss $\Lambda$

orp!u!jरydeis

orpisnpoy

วep!^npoy

oup!anpoy

כ:p!^npoy

oep!^npay

әер!^npoy

oxpi^npoy

nuit)

oxp!^npoy

эep!^npoy

วrpi^npoy

oxp!wojejusd

sep!wojejusd e!pul

oxp!uolejuad sep!wojelusd

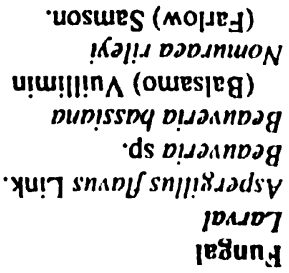

(10!!!ed) !!!ussu pussoN

$\mathrm{u} \cdot \mathrm{ds}$ ab.rm!! mudso $\mathrm{N}$

joll!ed osdn.ood.p.) puasoN

-ds puasoN

-ds DiussoN

[DASD?

cozojodd

SNA2OH.LVd

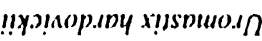

(poij!uap!un) şoנj oad

sad $K_{1} 2$ sputq ooyonj

u!pnea . 10 (o.)!s.s. sasopo

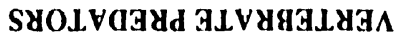

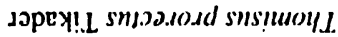

Jopex!」 snscryo/ sns!muoll.l.

sapex!! sisursqufund sndd!p!!yd

sopex! L ! Ippumu nss!d.ın $W$ -ds vssid.It)W

yoosod !nollyino..in sndokx $O$ ds sadosixo

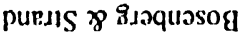

sclo.)!.).

uouu!s s:x(!n.)umd s'o!!lo

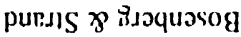

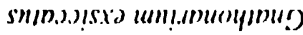

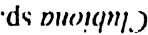

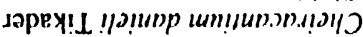

pasd']

SX'ACIIS

ds p!p!ntoly

sqed mus!ls sims!nod

' $\mathrm{l}$ व a asinpol sus!lod

(d) sisusu!n.) sass!yod

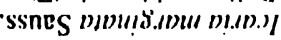

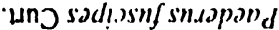

ds sassolownpayds

id sod!.ssinf s!o.o.xouniy

('y!! s) s!jmbs' s!.(1).)(m!!!y

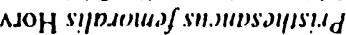

'

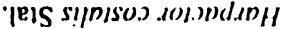
ds sn.ı⿻⿰丨丨

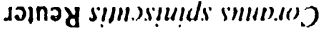

(i) ')

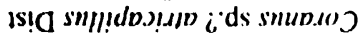

(Kes) s!alu⿰冫! (ps!og) smymub.mpau sndeucip/d

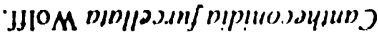

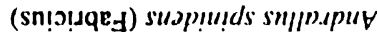


Table 2 Contd.

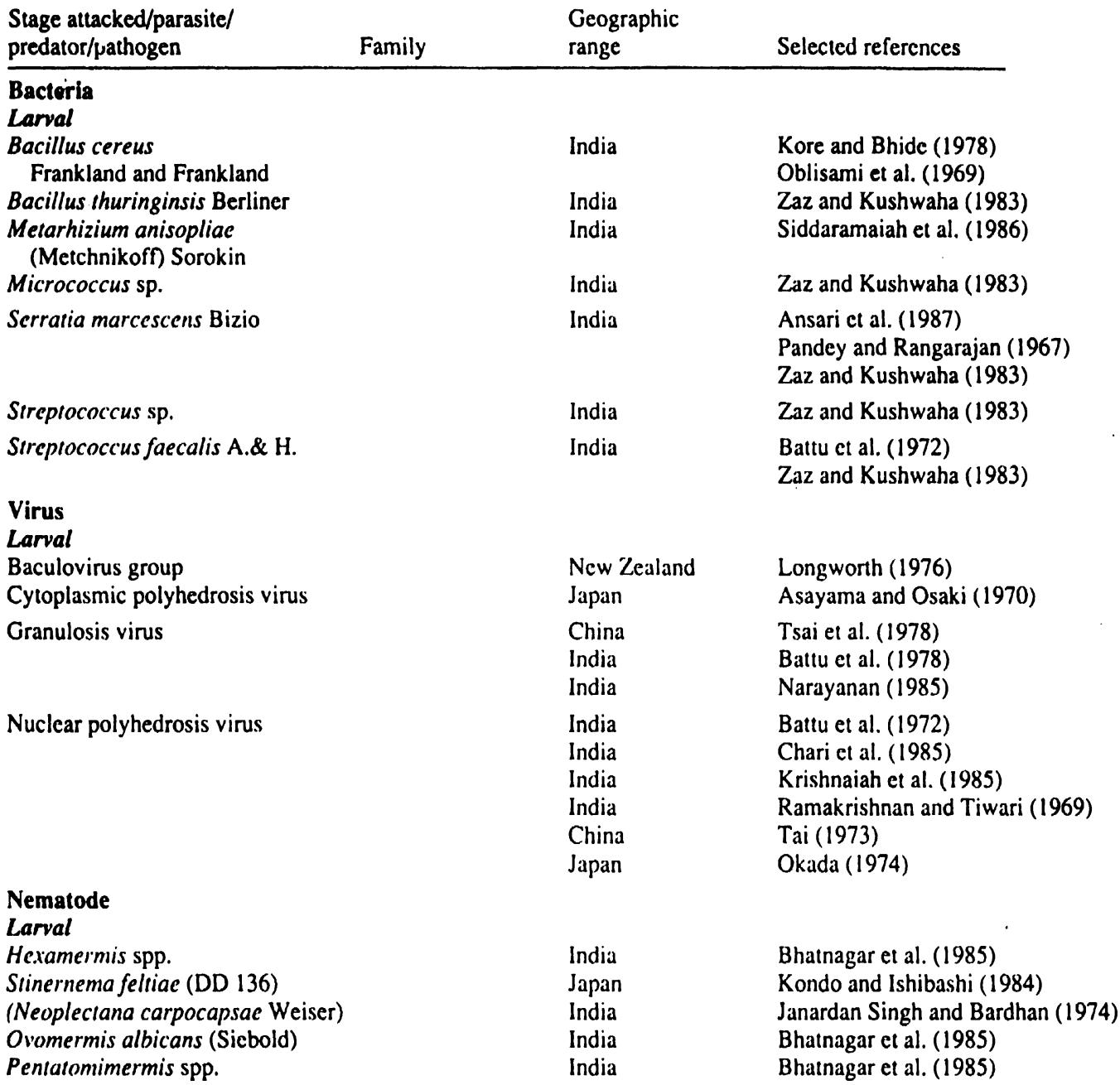

(1976) reported that $T$. dendrolimi is an egg parasitoid of $S$. litura from Taiwan.

Braune (1982) found Telenomus remus Nixon to be a common egg-larval parasitoid of $S$. litura in Western Samoa with parasitism averaging $54 \%$. Complete parasitization was observed only in small egg masses (up to 150 eggs) and the percentage of parasitization decreased with an increase in size of egg-mass. T. remus could oviposit only in host eggs on the surface of the host egg mass. Thus, the effectiveness of $T$. remus was limited on the large compact egg masses of $S$. litura.

\section{LARVAL PARASITOIDS}

Generally, the larval stage of S. litura is more prone to parasitism. Larval parasitoids of $S$. litura attack young to mature larvae and a few also attack eggs and larvae, and larvae and prepupae. Fifty-eight parasitoid species have been reported to attack the larval stage of this species. Of these, $47 \%$ were braconids, $19 \%$ ichneumonids, $16 \%$ tachinids, $10 \%$ eulophids, $3 \%$ chalcids, and $2 \%$ scelionids, encrytids and muscids. In general, $84 \%$ were Hymenoptera, and $16 \%$ Diptera.

In India, 32 different species of parasitoids have been reported as larval parasitoids of S. litura. Among these, Apanteles and Bracon sp. were the most commonly reported. In 1974, Rai surveyed vegetable crops in the state of Kamataka and found that $10 \%$ of larval mortality was caused by Chelonus formosanus (Sonan). Battu (1977), during a survey of castor and cauliflower in the Punjab, found that $P$ arasarcophaga misera (Walk.) and Campolitis sp. also attack $S$. litura larvae. Jayanth and Nagarkatti (1984) reported the emergence of up to 12 tachinid parasitoids [Peribaea orbata (Wideman)] from a single S. litura larva in Karnataka state, India.

Rao and Satyanarayana (1984), during a pest survey of natural enemies of $S$. litura in Andhra Pradesh, India, reported Zele chlorophthalma Nees 
as a larval parasitoid and Lasiochacidia erythropodus Nees as a pupal parasitoid.

Sathe (1987) in a survey for natural enemies of $S$. litura in Maharashtra region of India reported Compoletes chloridae Uchida and Apantele's colemani Viereck. During the same survey two new Braconid species (Enicospilus sp. and Echthromorpha sp.) were found responsible for the $5 \%$ parasitization of S. litura while A. colemani and A. prodeniae parasitized up to $20 \%$ larvac.

Laboratory tests to determine the effect of host plants on the degree of parasitism of $S$. litura larvac by Cotesia (Apanteles) marginiventris Cresson, showed least preference for larvae on tobacco (Jalali et al., 1987). Although $20 \%$ of the larvac were parasitized on tobacco leaves, female parasitoids became inactive after contact with the leaves and died within $1 \mathrm{hr}$ suggesting that $C$. marginiventris would not be suitable for release against $S$. litura on tobacco. The most preferred host for the parasitoid was Khol rabi (56\% parasitization).

Application of $2 \%$ neem (Azadiracta indica) kernel suspension to eggs of $S$. litura before and after parasitization by Telenomus renus Nixon had no effect on the development of the parasitoid in India (Joshi et al., 1982). Thus, neem seed kemel suspension was considered suitable in the integrated control of $S$. litura in tobacco nurseries.

Six parasitoid species, Apanteles ruficrus (Hal.), C. marginiventris (Cresson), A. kazak Telenga, Compoletes chloridae Uchida, Hyposoter didymator Thumb and Telenomus remus Nixon were introduced to Western Australia from overseas in 1978-1983 and released against S. litura and 11 other economically important pests. The highest level of parasitism by $A$. ruficrus was noticed in Mythimna sp. (80\% and above; Michael et al., 1984).

In Western Samoa, Stechmann and Semisi (1984) collected information on $S$. litura damage levels in relation to natural populations of Apanteles sp. in the taro fields. They found that this pest is more severe on "Taro" crop where insecticides and herbicides were widely used, which perhaps created imbalance between the pest and its natural enemies. Barrion and Litsinger (1987) reported the presence of Peribaea orbata (Wideman) as a gregarious larval parasitoid on S. litura.

\section{PUPAL PARASITOIDS}

Relatively few pupal parasitoids have been reported from S. litura when compared to parasitoids of other life stages. Eight parasitoid species have been reported from the pupal stage of $S$. litura, one of them is a larval - pupal parasitoid (Ichneumon sp.) and one a prepupal parasitoid (Chelonus sp.; Table 2).

Lasiochalcidia erythropodus Cameron was reported as a pupal parasitoid of S. litura in Andhra Pradesh, India (Rao and Satyanarayana, 1984). However, Bhatnagar (1981) reported this species as a larval parasitoid.

\section{PREDATORS}

Altogether 36 predatory insects from 14 families and 12 species of spiders, representing six families were reported to feed on $S$. litura eggs, larvae and pupae in different parts of the world. Of the total predators reported to feed on S. litura, 50\% of the insect predatory fauna and $83 \%$ of the spiders were from India (Table 1).

Sitaramaiah et al. (1975) from Andhra Pradesh, India, observed for the first time the reduvid Harpactor costalis Stal. predating on S. litura larvae in tobacco crops. Laboratory experiments revealed that the predator consumes an average of $63 \mathrm{~S}$. litura larvae during its life span.

Nymphs and adults of Andrallus spinidens ( $F$.) (pentatomid) were observed feeding on S. litura larvae in rice in Himachal Pradesh, India (Pawar 1976). Another pentatomid species, Canthoconidia furcellata (Wolf), was observed feeding on larvae of S. litura in tobacco nurseries in Andhra Pradesh, India (Kapoor et al., 1975). The biology of this predator was studied in the laboratory with a view to use $C$. furcellata in an integrated pest management programme for tobacco pests.

Nakasuji et al. (1976) observed a predatory wasp. preferentially selecting fifth and sixth instar larvac over carly instars. The wasps were more active and attacked more larvae in fields with high larval density than those with low larval density. However, the percentage of predation was lower in the field with highest density of $S$. litura larvae.

Chu (1979), from a survey in Jawa Timur, Indonesia, reported a carabid beetle, Casnoidia indica (Thnb.) and a staphylinid beetle Paederus fuscipes Curt, feeding on S. litura and other economically important lepidopterous insects. Chu and Chu (1975) studied the effects of temperature on the growth of $C$. furcellata and found that 71,216 and $134 \mathrm{C}$ degree days were required for egg, nymph and adult stages, respectively. It was concluded that there are five to six generations per year of this predator in northern Taiwan.

Deng and Jim (1985) reported Conocephalus sp. (Tettigometridae) as new predator on egg masses of S. litura in Guangxi, China. This katydid was 
successfully reared on artificial diet. Field releases of nymphs and adults of Conocephalus sp. were attempteci against the control of Scirpophaga incertulus (Walk.).

\section{DISEASES}

\section{Protozoa}

Nosema carpocapse Paillot was found to infect $S$. litura larvae in New Zealand (Malone and Wigley, 1980), India (Narayanan and Jayaraj, 1979), Japan (Watanabe, 1976) and China (Tsai et al., 1978; Li and Wenn, 1987).

\section{Bacteria}

Seven bacteria are known to infect S. litura at larval stage in India (Table 2). Ansari et al. (1987) reported Serratia marcescens Bizio from Karnataka, India, attacking larvae of the noctuids Helicoverpa armigera Hübner and $S$. litura. In labortory tests, $S$. litura was found more susceptible to the bacterium than $H$. armigera. The bacterium was equally pathogenic when ingested through artificial diet or the natural food plant, but pathogenicity by contact application to the body of larvae was poor.

Zaz and Kushwaha (1983) found Bacillus thuringiensis Berliner (B.t.) to be an effective microbial insecticide against $S$. litura larvae in cauliflower fields in Rajasthan, India. Application of the B.t. in combination with endosulfan resulted in $85 \%$ larval mortality in the ficld.

\section{Fungi}

So far four fungi have been reported to infect $S$. litura and cause physiological disorders in larval growth and development. Asayama and Ohoishi (1980) from Japan and Phadke and Rao (1978) from India, investigated the pathogenicity of a green muscardine fungus Nomuraea rileyi (Farlow) Samson. Laboratory studies in India indicated that this fungus was harmless to eggs of an egg parasitoid, Telonemus proditor Nixon, on Achea janata L., and recommended the combined use of the fungus and the egg parasite in biocontrol programmes against $A$. janata. This may also apply to $S$. litura management.

Zaz and Kushwaha (1983) reported Beauveria bassiana (Balsamo) Vuillemin. infecting S. litura in cauliflower crops in Rajasthan. Siddaramaiah et al. (1986) reported an incidence of larval infection with Metarhizium anisopliae (Metchnikoff) Sorokin in groundnut in Karnataka. The infection first appeared in the second fortnight of June, was highest in midAugust, and decreased by November.

\section{Virus}

Viral diseases of this species have been reported from China, Japan, India and New Zealand. Among the viruses, nuclear polyhedrosis viruses are the most common and potent.

Krishnaiah et al. (1985) conducted field trials with a nuclear polyhedrosis virus against $S$. litura damage in black gram (Vigna mungo) fields in Andhra Pradesh, India. Two sprays of virus suspension containing $1.96 \times 10^{9}$ polyhedral inclusion bodies $/ \mathrm{ml}$ at the rate of $1500 \mathrm{ml} / \mathrm{ha}$. gave effective control similar to chemical insecticides tested.

Chari et al. (1985) evaluated the effectiveness of integrated management of natural enemies and viral diseases to control S. litura on tobacco scedlings in Gujarat, India. They concluded that a combination of biological control agents, insect growth regulators, antifeedants and a trap crop on all sides of a nursery is an ecologically sound procedure for the control of S. litura.

Narayanan (1985) from Karnataka, reported the occurrence of a granulosis virus in dead S. litura larvae. Eggs and all six larval instars were highly susceptible to the virus, the mortality was $100 \%$ in eggs and first to fifth instar larvae and 50\% in the last larval instar. The disease killed older larvae more rapidly than the younger ones.

\section{Nematodes}

Four nematode species have been reported parasitizing S. litura in India and one of them has also been reported to be parasitizing $S$. litura in Japan.

Bhatnagar et al. (1985), found S. litura larvae parasitized by the mermithid nematodes, Ovomermis albicans (Siebold), Hexamermis sp., and Pentatomermis sp. They observed more nematode activity on alfisols than on vertisols. They also discussed the population dynamics and distribution of nematodes and the arthropod hosts. Kondo and Ishibashi (1984) explained the infectivity and propagation of entomogenous nematodes Steinernema sp. on S. litura from Japan.

\section{CONCLUSIONS}

Although 71 parasitoids and 48 predators are known to attack $S$. litura at different stages, most of these associations were incidental, either some species were rare or more closely associated with other hosts. 
Among the pathogens, five protozoans, four fungi, seven bacteria, four viruses and four nematodes are known to infect the larval stage of S. litura. All reports of bacterial infections are from India.

Among the 10 species of egg parasitoids reported the genus Trichogramma was the most widely distributed in India, Indonesia and China. More larval parasitoids have been reported from S. litura, $83 \%$ of the parasitoids are hymenopterous and the remaining $17 \%$ were dipterous. The parasitoids that attack the pupal stage are relatively fewer in number. Only eight species have been reported, one of which was a larval pupal parasitoid and another prepupal parasitoid.

Altogether 48 species of insects and spiders were observed to predate on eggs, larvae and pupae of $S$. litura. Spiders account for $25 \%$ of the total predators.

In the past, the mass releases of egg and larval parasitoids for the control of S. litura in different crops in different geographical regions had achieved only partial success (Patel et al., 1979; Michael et al., 1984). Our personal observations in ICRISAT groundnut fields revealed more leaves with defoliator damage in insecticide applied fields than unsprayed areas (Wightman et al., 1990). Similar observations were also made during farmers' field surveys in the post-rainy season in Coastal Andhra Pradesh, India (Ranga Rao and Shanower, 1988). Stechmann and Semisi (1984) also shared the same opinion after surveying Taro fields in Western Samoa. In view of the development of insecticidal resistance and the destruction of the natural enemies and the polyphagous nature of this species, there is need to give more consideration to the role of natural enemies as a component in integrated approaches to manage this species.

\section{REFERENCES}

Anonymous (1977) Report of the Department of Scientific and Industrial Research for the year ended 31 March 1977. New Zealand. 70 pp.

Anonymous (1988) Annual Report - International Crops Research Institute for the Semi-Arid Tropics(ICRISAT), Patancheru, Andhra Pradesh, India.

Ansari M. A., Pawar A. D. and Ahmed S. N. (1987) A note on pathogenicity of naturally occurring bacterium Serratia marcescens Bizio on some lepidopterous pests. Plant Prot. Bull.India 39, 27 28.

Asayama T. and Ohoishi K. (1980) Field infection of Spodoptera litura (F.) larvae by the entomogenous fungus, Nomuraea rileyi (in
Japan) and morphology of the fungus grown on the larvae. Japanese J. Appl. Entomol. Zool. 24, 105-107.

Asayama T. and Osaki N. A. (1970) Cytoplasmic polyhedrosis of the cotton leaf worm, Prodenia litura (F.). J. Invertebr. Pathol. 16, 292-294.

Ayyanna T., Arjuna Rao P., Subba Ratnam G. V. Krishna Murthy B. H. and Narayana K. L. (1982) Chemical control of Spodoptera litura (F.) on groundnut crop. Pesticides 16, 19-20.

Barrion A. T. and Litsinger J. A. (1987) A larval parasite of swarming caterpillar and common cutworm in the Philippines. Int. Rice Res. Newsl. 12, 34-35.

Battu G. S. (1977) Occurrence of Parasarcophaga misera (Walker) and Campoletis sp. as parasites of Spodoptera litura (F.) from India. Current Sci. 46, 568-569.

Battu G. S., Bindra O. S. and Rangarajan M. (1972) Investigations on microbial infections of insect pests in the Punjab. Indian J. Entomol. 33, 317325.

Battu G. S., Dilawari V. K. and Bindra O. S. (1978) Investigations on microbial infections of insect pests in the Punjab-II. Indian J. Entomol. 39, 271-280.

Bhanotar R. K. and Srivastava Y. N. (1985) Impact of reptiles on food production and environment. Non insect pests and predators. Proc. of the National Symposium on Impact of Non Insect Pests and Predators Food Production and Environment. March 12-14, 1984 India. All India Scientific Writers Society. pp. 116-120, 265-266.

Bhatnagar V. S. (1981) Arthropod parasitoids of insect pests (excluding Heliothis sp.) recorded in Andhra Pradesh, India. Cropping Systems (Entomology) Progress Report, ICRISAT.

Bhatnagar V.S., Pawar C. S., Jadhav D. R. and Davis J.C. (1985) Mermithid nematodes as parasites of Heliothis sp. and other crop pests in Andhra Pradesh, India. Proc. of Indian Academy of Sciences. Animal Sci. 94, 509-515.

Braune H. J. (1980) Field studies on taro cluster caterpillar. Alafua Agric. Bull. 5, 42-46.

Braune H. J. (1982) Effect of structure of host egg mass on the effectiveness of egg parasite of Spodoptera litura (F.) (Lepidoptera: Noctuidae). Western Samoa, Drosera 1, 7-16.

Braune H.J. and Kan S.K. (1981) Species composition and biology of the predator-parasite complex of the taro cluster caterpillar, Spodoptera litura (F.) in Western Samoa. Alfua Agric. Bull. 6, 46-50.

Braune H. J., Kan S. K. and Treviranus H. (1981) 
Studies on the effectiveness of Apanteles sp. a larval parasite of Spodoptera litura (F.). Alafua Agric. Bull., Apia; Western Samoa. 6, 12-22.

Chari M. S., Bharpoda T. M. and Patel S. N. (1985) Studies on integrated management of Spodoptera litura (F.) in tobacco nursery. Tobacco Res. 11 , 93-98.

Cherian M. C. and Brahmachari K. (1942) Note on three predatory Hemipterians from South India. Indian J. Entomol. 3, 115-119.

Chiu S. C. and Chou L. Y. (1976) Hymenopterous parasitoids of Spodopteralitura (F.).J.Agric. Res. of China 25, 227-241.

Chu Y. I. (1979) Some notes on the lepidopterous rice insect pests at Jawa Timur, Indonesia. Nat. Taiw'an Univ. Phytopathol. Entomol. 6, 38-43.

Chu Y. I. and Chu C. M. (1975) Life history and the effect of temperature on the growth of Eocanthecona furcellata (Wolff). Plant Prot. Bull., Taiwan 17, 99-114.

Deng G. Y. and Jim M. X. (1985) Study on a predacious katydid Conocephalus sp. Chinese J. Biocontr. 1, 8-11.

Feakin S. D. (1973) Pest control in groundnuts. PANS Manual No. 2, London COPR, ODA.

Hafez M. (1951) Notes on introduction and biology of Microplietis demolitor Wilk. (Hymenoptera: Braconidae). Bull. Soc. Fouad. Icr. Entomol. 35 , 107-121.

Hassan E. (1972) Problems of applied entomology in Papua New Guinea. Anz. Schadlingsk. Pflanzenschutz. 45, 129-134.

Hokyo N. and Hawanthai S. (1975) The effect of prey size and prey density on the functional response, survival, growth and development of a predatory Pentatomid bug, Podisus maculiventris Say. Res. Popul. Ecol. 16, 207-218.

Hoyt C. P. (1955) Notes on larvaevorid flics reared from Prodenia litura Fab. and Otheris fullonica (Clerk) larvae in American Samoa. Proc. Hawaii Entomol. Soc. 15, 419-421.

Ito Y., iamanaka H., Nakasuji F. and Kiritani K. (1972) Determination of predator-prey relationship with an activable tracer, europium151. Kontyu 40, 278-283.

Jalali S. K., Singh S. P. and Ballal C. R. (1987) Rolc of host plants on Spodoptera litura (F.) on the degree of parasitism by Cotesia marginiventris (Cresson) (Hymenoptera:Braconidae). Indian J. Agric. Sci. 57, 676-678.

Janardan Singh and Bardhan A. K. (1974) Effectiveness of DD-136, an entomophilic nematode against insect pests of agricultural importance. Current Sci. 43, 622.
Jayanth K. P. and Nagarkatti S. (1984) Record of true parasitism in Peribaea orbata (Wied) (Diptera:Tachnidae). Entomon 9, 77-78.

Joshi B. G., Ramaprasad G. and Sitaramaiah S. (1982) Effect of neem seed kemel suspension on Telenomus remus, an egg parasite of Spodoptera litura (F.). Phytoparasitica 10,61-63.

Joshi B. G., Sitaramaiah S., Satyanarayana S. V. V. and Ramprasad G. (1979) Note on natural enemies of Spodoptera litura (F.) and Myzus persicae (Sulz.) on flue cured tobacco in Andhra Pradesh. Science and Culture 45, 251-252.

Kapoor K. N., Gurarate J. P. and Gangrade G. A. (1975) Cantheconidia furcellata Wolff. as a predator of Prodinia litura Fabr. larvae. Indian J. Entomol. 35, 275.

Kondo E. and Ishibashi N. (1984) Infectivity and multiplication of Steinernema feltiae (Str. Mexican) on common cutworm, Spodoptera litura (F.). Japanese J. Appl. Entomol. Zool. 28, 229-236.

Kore S. S. and Bhide V.P. (1978) Bacterial disease of tobacco caterpillar Spodoptera litura (F.). J. Maharashtra Agric. Univ. 3, 34-37.

Kranz J., Schumutterer H. and Koch W. (eds) (1977) Diseases Pests and Weeds in Tropical Crops. Berlin and Hamburg: Verlag Paul Parley.

Krishnaiah K., Ramakrishnan N. and Reddy P. C. (1985) Control of Spodoptera litura (Fabr) on black gram by nuclear polyhedrosis. Indian J. Agric. Sci. 55, 775-776.

Longworth J. F. (1976) Insect viruses and pest control. Search for alternatives. New Zealand J. Agric.132, 16-17.

Li S. P. and Wenn C. S. (1987) Nosema liturae sp. a new species of microsporidia from the cotton leaf worm Spodopteralitura. Sci.Agric. sinica 20,7174.

Malone L.A. and Wigley P.J.(1980) The distribution of Nosema carpocapsae, a protozoan pathogen of the codling moth, Cydia pomonella (Lepidoptera: Tortricidae), in New Zealand. New Zealand Entomol. 7, 151-153.

Michael P. J., Woods W., Lawrence P. J., Fisher W., Bailey P. and Swincer P. (1984) Introduced parasites for the control of Australian noctuid pests. Proc. of the Fourth Australian Applied Entomological Research Conference, Adelaide 24-28 September 1984. Pest Control Recent Advances and Future Prospects (Edited by Bailey P. and Swincer D.) pp.294-303.

Moussa M. A., Zaher M. A. and Kotby F. (1960) Abundance of the cotton leaf worm, Prodenia litura (F.) in relation to host plants. I. Host plants 
and their effect on biology (Lepidoptera: Agrotidae). Bull. Soc. Entomol. Egypti 44, 241251.

Nakasuji F., Yamanaka H. and Kiritani K. (1973) The disturbing effect of Micryphantid spiders on the larval aggregation of the tobacco cutworm. Spodoptexa litura (F.) (Lepidoptera: Noctuidae). Kontyu 41, 220-227.

Nakasuji F., Yamanaka H. and Kiritani K. (1976) Predation of larvae of the tobacco cutworm Spodoptera litura (F.) (Lepidoptera, Noctuidae) by Polistes wasps. Kontyu 44, 205-213.

Narayanan K. and Jayaraj S. (1979) Spodoptera litura (F.) as a host for Nosema sp. Current Sci. 48, 276.

Narayanan K. (1985) Susceptibility of Spodoptera litura(F.) to.a granulosis virus. Current Sci. 54 , 1288-1289.

Narendran T. C. and Joseph K. J. (1977) Studies on Some Aspects of Host-Specificity with Reference to Brachymeria lasus Walker, a Polyphagous Chalcid Parasite of Lepidopterous Insects. The Macmillan Company of India Lid., India, 85-89.

Oblisami G., Ramamoorthi K. and Rangaswami G. (1969) Studies on the pathology of some crop pests of South India. Mysore J. Agric. Sci. 3, 8698.

Okada T. (1974) Persistence of viral activity of Spodoptera litura $(\mathrm{F}$.) nuclear polyhedra sprayed in mixtures. Proc. of the Association of Plant Protection of Kyushu 20, 37-39.

Pandey S. N. and Rangarajan M. (1967) Prodenia litura F. a new host of Serratia marcescens Bizio. Indian J. Entomol. 29, 14-17.

Patel J. S. (1944) Indian Central Jute Committee, Calcutta, India. Annual Report of Agricultural Research Scheme for the year 1942-1943. pp. 43-44.

Patel N. G. (1980) The bionomics and control measures of tobacco bug, Nesidiocoris tenuis Retutrg (Miridae Hemiptera). Gujarat Agric. Univ. Res. J. 5, 60.

Patel R. C., Patel J. C. and Patel J. K. (1971) New records of parasites of Spodoptera exigua $(\mathrm{Hb}$. and Spodoptera litura (Fabricius) from Gujarat. Indian J. Entomol. 1972. 33, 92-93.

Patel R. C., Yadav D. N. and Saramma P. U. (1979) Impact of mass releases of Chelonus helepae Gupta and Telenomus remus Nixon against Spodoptera litura(Fabricius).J.Entomol.Res.3, 53-56.

Pawar A. D. (1976) Andrallus spinidens (Fabricius) (Asopinae: Pentatomidae: Hemiptera) as a predator of insect pests of rice in Himachal
Pradesh, India. Rice Entomol. Newsl. No. 4, pp. 23-24.

Phadke C. H. and Rao V. G. (1978) Studies on the entomogenous fungus Nomuraea rileyi (Farlow) Samson 1. Current Sci. 47, 511-512.

Rai P. S. (1974) Record of Chelonus formosanus (Sonan) (Hymenoptera: Braconidac), a parasite of Spodopicra litura (Fabricius) from Mysore State. Current Sci. 43, 30.

Ramakrishnan N., Saxena V. S. and Dhingra S. (1984) Insecticidal resistance in the population of Spodoptera litura (F) in Andhra Pradesh. Pesticides 18, 23-27.

Ramakrishnan N. and Tiwari L. D. (1969) Polyhydrosis virus of Prodenia litura Fabricius (Noctuidae: Lepidoptera). Indian J. Entomol.31, 191-192.

Ramamurthy K., Oblisami G. and Rangaswami G. (1967) An epizootic fungus disease of sunhemp pests. The Mysore J. Agric. Sci. 1, 225-226.

Ranga Rao G. V. and Shanower T. G. (1988) A survey of groundnut insect pests in Andhra Pradesh, post rainy season, 1987-1988. Int. Arachis Newsl. 4, 8-10.

Rao B. N. and Patel R. C. (1976) Bionomics of Chelonus formosanus Sonan. An egg-larval parasite of Spodoptera litura (F.). Indian J. Entomol. 36, 103-109.

Rao K. J., Thontadarya T. S. and Rangadhamaiah K. (1979) A note on the survival and parasitism of the egg-larval parasite Chelonus blackburni Cameron (Hym.: Braconidae) on some lepidopterous hosts. Current Res. 8, 48-50.

Rao R. S. N. and Satyanarayana S. V. V. (1984) Note on more additions to the natural enemy complex of Spodoptera litura (F.) and Myzus persicae Sulz. on tobacco in Andhra Pradesh. Current Sci. 53, 201-202.

Rao R. S. N., Satyanarayana S. V. V. and Soundararajan V. (1981) Note on new additions to the natural enemies of Spodoptera litura (F.) and Myzus persicae Sulz. on flue cured tobacco in Andhra Pradesh. Science and Culture 47, 9899.

Rao V. G. and Phadke C. H. (1977) A muscardine disease of tobacco leaf-eating caterpillar. Current Sci. 46, 648-649.

Ren S.Z. (1984) Studies on the genus Coranus curtis from China. Entomotoxonomia 6, 279-286.

Richard K. T. (1964) Insect pests of cotton in the ORD River irrigation area. The J. Agric. Western Australia 5, 15.

Sathe T. V. (1987) New records of natural enemies of Spodoptera litura (Fab.) in Kolhapur, India. 